\title{
PSYCHE
}

VOL. XXVII

AUGUST, 1920

No. 4

\section{EUPONERA GILVA (ROGER), A RARE NORTH AMERICAN ANT.}

By W. M. Wheeler and F. M. Gaige, Bussey Institution, Harvard University and University of Michigan.

In 1863 Julius Roger described, among other North American Formicidæ, Ponera gilva and Discothyrea testacea, two species which the senior author has vainly sought for the past twenty years, both in the field and in the numerous collections sent him for identification. "Nordamerika" was the only locality appended to the descriptions, and as the other species of the two genera are tropical or subtropical it was natural to infer that Roger's types were taken somewhere in Mexico. The Discothyrea is still to be rediscovered, but recently the junior author succeeded in taking four workers of gilva in northwestern Tennessee.

In his most recent revision of the Ponerinæ (1910) Emery refers this species to the subgenus Trachymesopus of the genus Euponera. He divides the species of the subgenus into three groups: those with small, but developed eyes in the worker (stigma group), those with very minute, vestigial eyes in the same caste (ochracea group), and those known only from female specimens (darwini group). The first group comprises several species of which the best-known, E. stigma Fabr., is common throughout tropical America and even has a variety, quadridentata Smith, in the Indomalayan and Papuan Regions. The typical form of the species occurs also in Florida, since Father J. Schmitt many years ago gave the senior author a worker captured at Fort Worth. To the ochracea group Emery assigns three species: gilva Roger, ochracea Mayr of the Mediterranean Region (according to Forel with a subspecies, guatemalensis, in Guatemala!) and sauteri Wheeler of Japan. To the group known only from female specimens two species are assigned: darwini Forel, which occurs in Northern Australia, India, Indonesia, Madagascar and the Congo, and crassicornis Emery from New 
Guinea. Since workers of darwini var. indica Emery, recently received by the senior author from the Philippines, have minute, vestigial eyes, this species must be transferred to the ochracea group.

The yellow or ferruginous coloration of both females and workers and the minute eyes of the latter in all the species of the ochracea group show that these ants must lead a concealed, hypogæic existence. The females of some of the species, notably of ochracea and darwini, are known to fly to lights and are therefore more frequently taken than the workers. But gilva must be either extremely rare or extremely local or its female would have turned up in some of the many collections made since 1863 . It would seem to be, in fact, an ancient relict on the verge of extinction. Its discovery in Tennessee, a region in which other interesting animal and plant relicts have survived, is not without significance. Since there is a Trachymesopus succinea Mayr, in the Baltic Amber, the subgenus goes back at least to the Lower Oligocene, but as only female specimens of this species are known it is impossible to say whether it bebelongs to the stigma or ochracea group.

Emery in his admirable paper on the North American ants, published in 1895, states that he has seen two worker cotypes of gilva from the Berlin Museum and besides adding somewhat to Roger's description, gives an excellent figure of the thorax. A more detailed description, with a figure (Fig. 1) of the head, body and middle leg, is appended.

\section{Euponera (Trachymesopus) gilva (Roger).}

Pondera gilva Roger, Berlin. Ent. Zeitschr. 5, 1863, p. 170 ; Mayr, Verh. zool. bot. Ges. Wien, 36, 1886, p. 438 \&; Dalla Torre, Catal. Hymen. 7, 1893, p. 39 \&; Emery, Zool. Jahrb. Abth. Syst. 8, 1895, p. 266, pl. 8, fig. $10 \&$; Wheeler, Ants, etc., 1910, p. $561 \%$.

Pachycondyla (Pseudoponera) gilva Emery, Ann. Soc. Ent. Belg. 45,1901 , p. 46 ६.

Euponera (Trachymesopus) gilva Emery, Genera Insect. Ponerinæ, 1910, p. 86.

Worker. Length 3-3.4 mm. Head shaped as in Ponera coarctata, slightly longer than broad, somewhat broader behind than in front, with feebly convex sides and nearly straight posterior border. 
Eyes very small, distinctly larger, however, than in E. ochracea, sauteri or darwini, at the anterior sixth of the sides of the head. Mandibles rather convex, with 6-7 distinct teeth, the apical somewhat coarser than the basal. Clypeus short, high and carinate in the middle, especially behind, depressed on the sides, with broadly rounded, entire anterior border. Frontal carinæ small, flattened, together forming a cordiform plate, divided by a narrow, impressed, longitudinal line, which runs back onto the head as far as the vertex in the form of a frontal groove. Antennal scapes not reaching the posterior border of the head by a distance somewhat greater than their greatest diameter; funiculi slender at the base and enlarged at the tip, all the joints, except the first and last distinctly broader than long; last joint nearly as long as the three preceding, which are subequal and form with it an indistinct club. Pronotum as long as broad, somewhat depressed above, with bluntly submarginate sides. Promesonotal and mesoëpinotal sutures pronounced, the mesonotum transversely elliptical, as high as the pronotum and feebly convex in profile. Epinotum shorter and narrower than the pro- and mesonotum together, laterally compressed at the base, broader behind, its dorsal outline in profile nearly straight, horizontal, lower than the mesonotum, longer than the declivity into which it passes rather abruptly, the latter feebly concave, distinctly marginate on the sides. Petiole from above transversely elliptical, a little broader than the posterior part of the epinotum, the node in profile broad below, a little lower than the epinotum, narrowing upward, with very feebly concave, steeply sloping anterior, flat, vertical posterior and evenly rounded dorsal surface; the ventral surface with a low, rounded projection in the middle. Postpetiole truncated in front, as long as, but distinctly narrower than the first gastric segment. Remaining segments rather small; sting well-developed, curved. Legs stout; middle tibiæ and metatarsi short and strongly bristly on their extensor surfaces.

Mandibles smooth, shining, with a few sparse punctures, mainly near the apical borders and some indistinct striæ near the base. Head opaque, very finely and densely punctate, so that it has a velvety texture. Thorax less opaque, especially the epinotum, and the fine punctures, especially of the latter, not so dense. Sides of epinotum, petiole, gester and legs shining, with very fine and still more distinctly separated punctures. 
Hairs and pubescence golden yellow, both poorly developed on the head, more abundant on the body and legs; the hairs erect, rather fine, moderately long, the pubescence long and rather coarse, not very closely appressed.

Ferruginous; legs and antennæ scarcely paler; head and mandibles a little darker, in some specimens with the occiput slightly infuscated.

Redescribed from four specimens taken August 30, 1919 by the junior author near Camden, Tennessee. The specimens were found four miles west of the town on a rather dry hillside covered with an open forest of second growth oak. The trees were small and so scattered that there was a ground cover of short wiry dry grass under them, with a few small shrubs and bushes. There was very little ground débris, as the natives seem to keep such picked up for firewood, but under a small stick, perhaps two feet long and three inches wide at its greatest width all four of the ants were found. The stick had evidently been lying in one position for a long time, as it was slightly buried, so that it came up with difficulty and disturbed the earth in loosening. The ants were in the soil beneath the stick, close together, but no evidence of a nest was seen. They were very sluggish and slow-moving, even more so than a few specimens of Stigmatomma pallipes Haldem, which were found in the same habitat. They made no effort to escape, seemed dazed and confused by the sudden disturbance, and one of them when picked up with the forceps and placed in the palm of the hand, feigned death for several seconds, with the antennæ drawn close to the head and the legs held tightly against the body.

\section{NOTE ON PTERERGATES IN THE CALIFORNIAN HARVESTER ANT.}

\section{By Harlow Shapley,}

Mount Wilson Observatory, Pasadena, California.

The phenomenon of vestigial wings in worker ants that otherwise are normal is of interest because of its significance in the problem of the origin of social castes among the Formicidæ, and also because of its infrequent occurrence. The recorded captures of workers with wing-vestiges are very few. Wheeler has taken three 

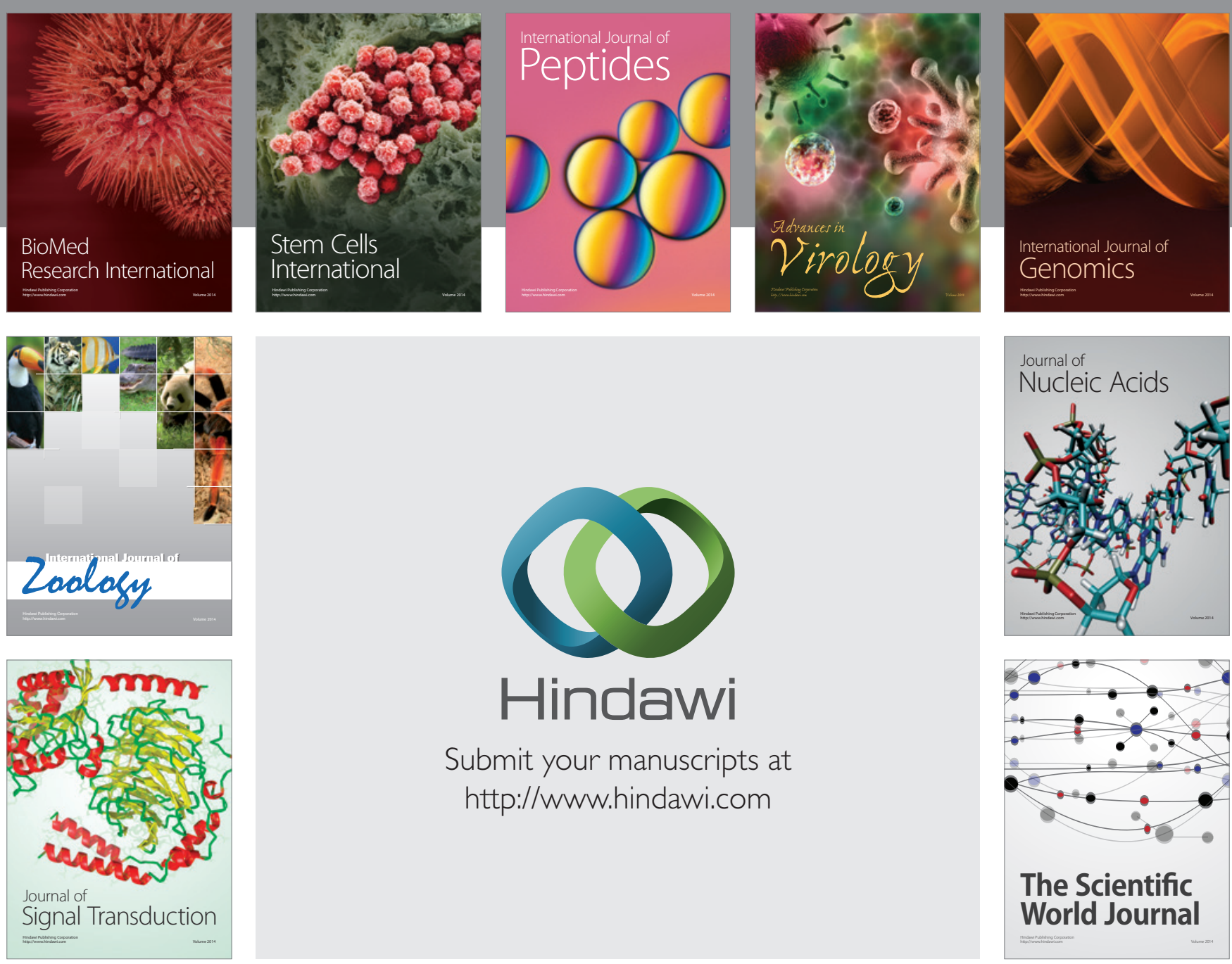

Submit your manuscripts at

http://www.hindawi.com
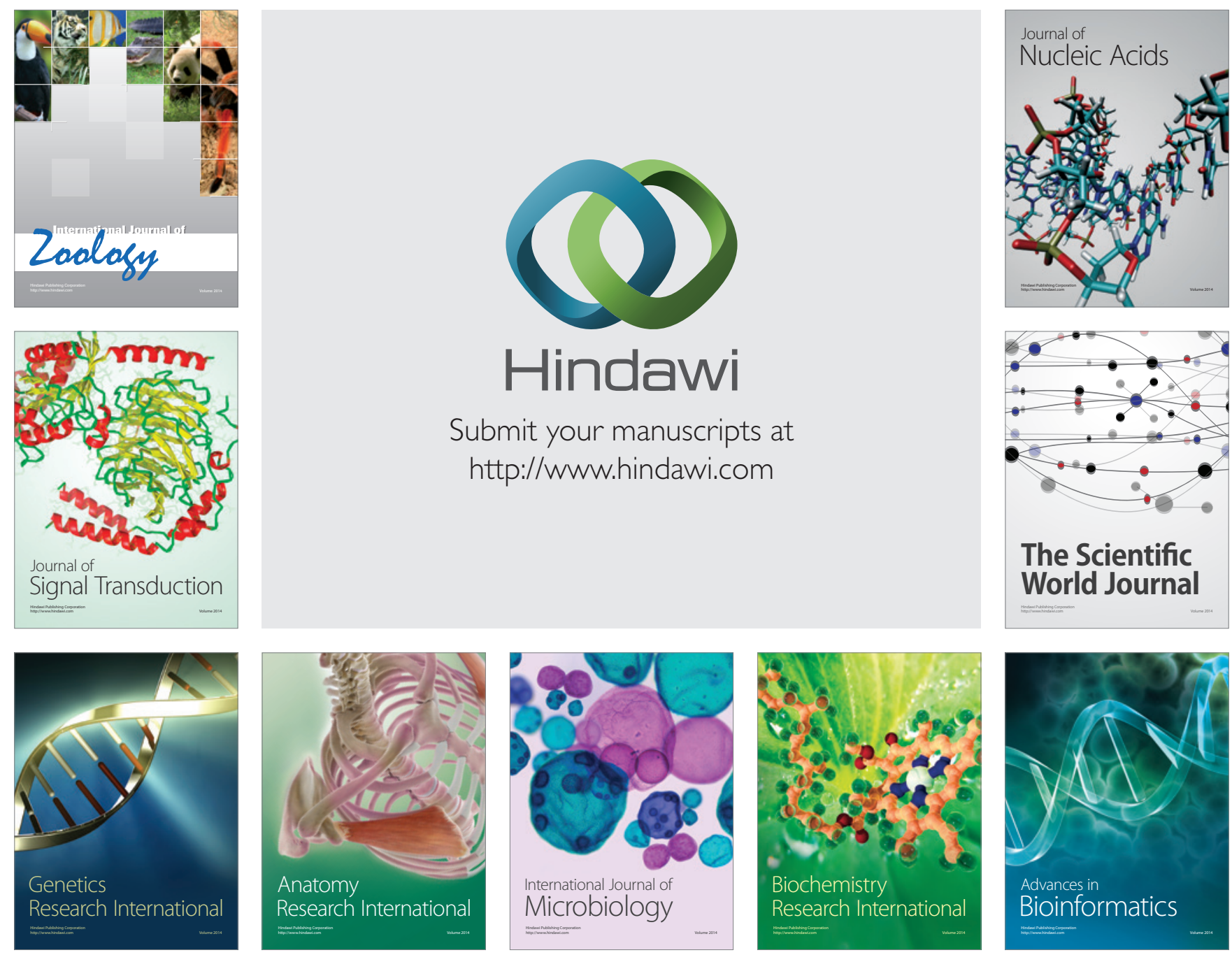

The Scientific World Journal
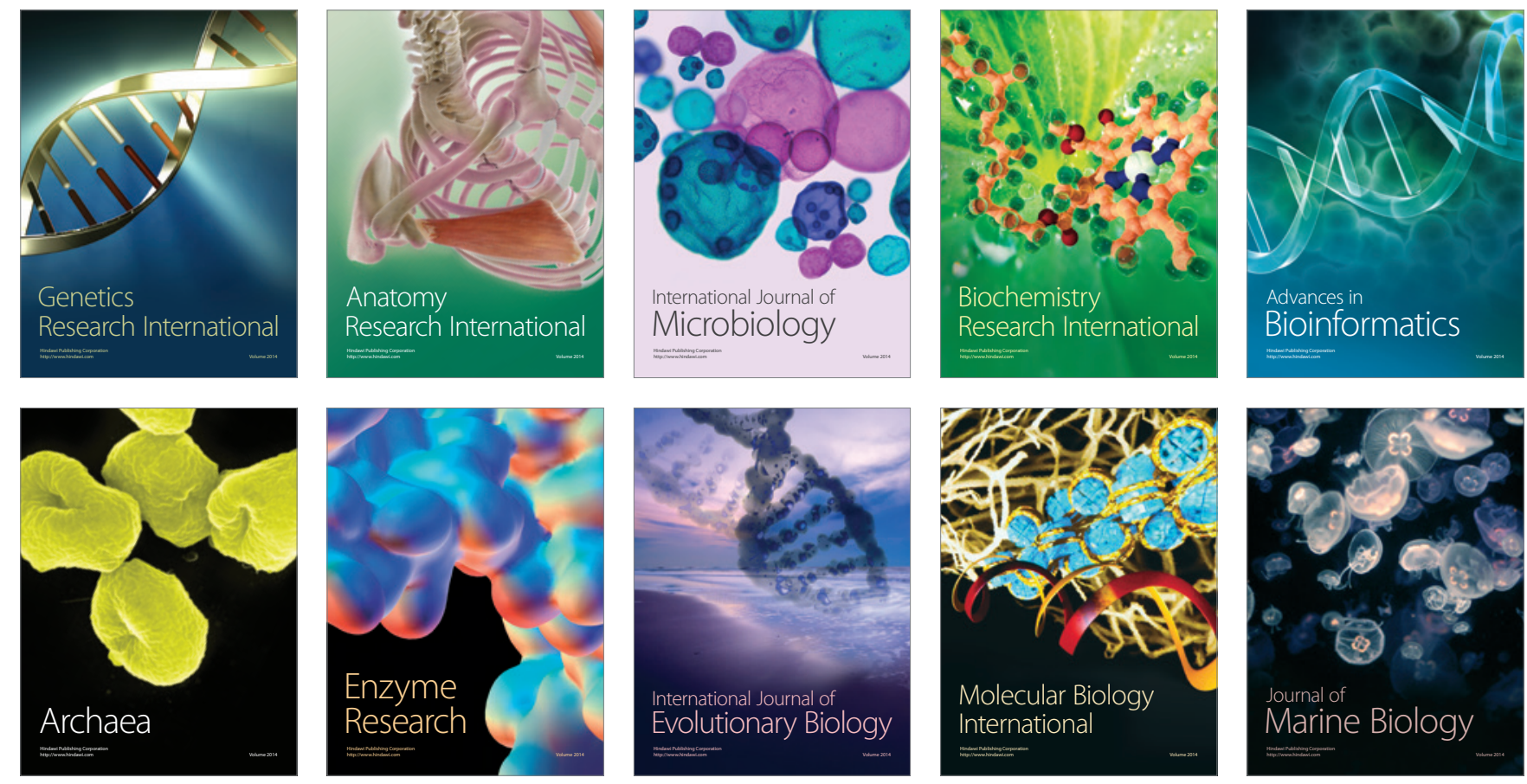